\title{
Working
}

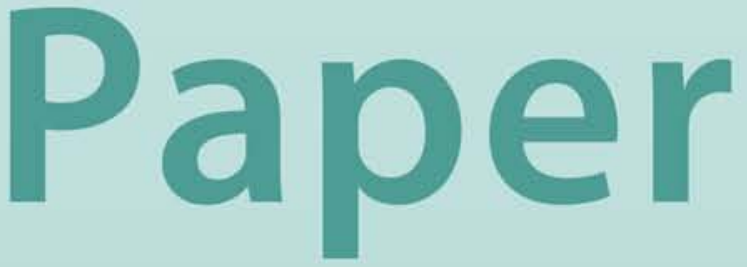




\section{Internal Models, Subordinated Debt, and Regulatory Capital Requirements for Bank Credit Risk}

Paul Kupiec 


\title{
IMF Working Paper
}

\section{Monetary and Exchange Affairs Department \\ Internal Models, Subordinated Debt, and Regulatory Capital Requirements for Bank Credit Risk}

\author{
Prepared by Paul Kupiec ${ }^{1}$ \\ Authorized for distribution by David Marston
}

September 2002

\begin{abstract}
The views expressed in this Working Paper are those of the author(s) and do not necessarily represent those of the IMF or IMF policy. Working Papers describe research in progress by the author(s) and are published to elicit comments and to further debate.
\end{abstract}

Shortcomings make credit VaR estimates an unsuitable basis for setting bank regulatory capital requirements. If, alternatively, banks are required to issue subordinated debt that has a minimum market value and maximum acceptable probability of default, banks must set their equity capital in a manner that limits both the probability of bank default and the expected loss on insured deposits, largely removing any safety net-related funding cost subsidy and the moral hazard incentives it creates. Required equity capital can be estimated using a modified credit-VaR framework, and supervisors can use external credit ratings to indirectly verify the accuracy of bank internal model estimates.

JEL Classification Numbers: G18, G20, G21, G28.

Keywords: regulatory capital requirements, credit VaR, subordinated debt, internal risk models.

Author's E-Mail Address:pkupiec@imf.org

${ }^{1}$ Paul Kupiec, Deputy Division Chief, Banking Supervision and Regulation Division, Monetary and Exchange Affairs Department, International Monetary Fund. Contact information: email pkupiec@imf.org; phone 202-623-9733; postal address: $70019^{\text {th }}$ Street NW, Washington, D.C., 20431, U.S.A. I am grateful to Matthew Jones for his comments on an earlier draft of this paper. 


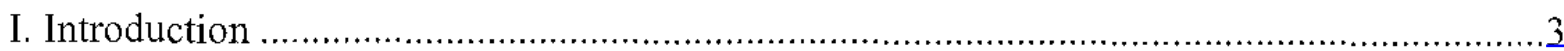

II. The Appeal of an Internal Models Approach for Capital Regulation ...............................

III. Internal Models and Regulatory Objectives ............................................................ 8

IV. Credit Risk and the Value of Safety-Net Guarantees ............................................ 2

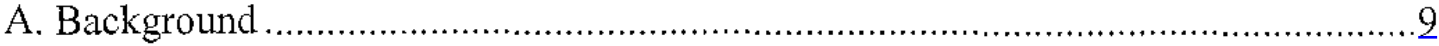

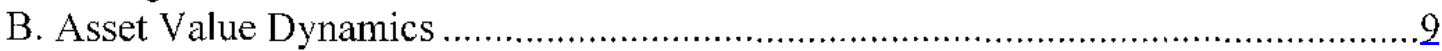

C. Deposit Insurance Value ......................................................................

D. Insurance Value and Risky Discount Bond Investments .................................1

V. Credit VaR and Buffer Stock Capital Allocation..................................................... 12

A. The Credil VaR Unexpected Loss Approach.............................................. 12

B. The Bias in Unexpected Loss Measures of Capital.........................................13

C. Calculating an Unbiased Buffer Stock Capital Estimate ..................................14

VI. Safety Net Externalities and Internal Models Capital Estimates..................................16

VII. Using Subordinated Debt to Implement an Internal Models Capital Regulation............19

A. Requirements on Subordinated Debt ..........................................................

B. Using Subordinated Debt and Internal Models to Set Equity Capital

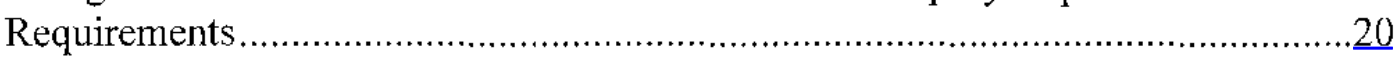

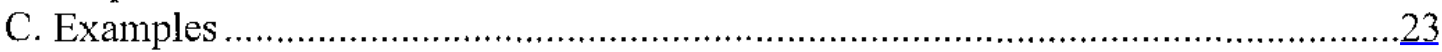

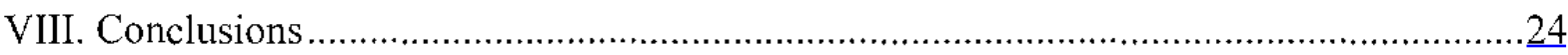

Text Tables

1. Regulatory Capital Requirements for Maturity-Matched Debt ...................................25

2. Regulatory Capital Requirements When Asset Maturity Exceeds Funding Debt ...............25

Figures

1. Insurance Value Under a HTM Internal Model Capital Requirement............................17

2. Insurance Value in Basis Points of Required Equity Capital .........................................19

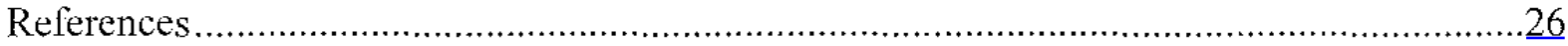




\section{INTRODUCTION}

This paper explores the possibility of using internal credit risk models as a basis for setting bank regulatory capital requirements for credit risk. Using the Black-ScholesMerton (BSM) equilibrium framework to model credit risk and estimate capital requirements, significant biases are shown to arise when capital allocations are based on credit-VaR (Value-at-Risk) unexpected loss estimates. Buffer stock capital requirements can be accurately estimated using an appropriately constructed internal models measurc, but this requires that reformulated credit $\mathrm{VaR}$ measures be augmented by an estimate of the equilibrium interest payments required by bank debt holders. These procedures for capital allocation differ from those discussed in the credit VaR literature and the Basel Committee on Banking Supervision (BCBS) consultative documents [Basel Committee on Banking Supervision (1999)] that survey bank practices.

The importance of including funding debt interest payments in buffer stock capital measures provides the key for understanding how bank internal capital estimates are affected by the externalities that are created when banks benefit from under priced safetynet guarantees. When safety nets provide banks with funding cost subsidies, banks can reduce their internal buffer stock capital allocations and still satisfy internal model capital requirements. Because the magnitudes of internal models capital "savings" are related to a credit's risk, these savings create distortions in a bank's optimal lending behavior. Analysis shows that even accurately constructed internal model capital estimates will not remove regulation-induced distortions in bank lending behavior.

While the credit VaR approach is suboptimal for setting regulatory capital requirements, it is possible to design a modified internal models approach for capital regulation that will satisfy regulatory objectives. The modifications that are required are intuitive and, unlike credit-VaR buffer stock capital estimates, the proposed capital estimates not only limit the probability of bank default, but also limit the bank's losses in default. The proposed regulatory capital framework also allows external credit ratings and observed capital market yields to be used as tools in the supervisory validation process.

We demonstrate that if a bank is requircd to issue subordinated debt in addition to its senior insured liabilities, it is possible to design an internal models approach to capital regulation that is largely unaffected by the shortcomings associated with credit-VaR based capital requirements. If capital regulations are specified in terms of a requirement that a bank fund its activities in part with a subordinated debt issue that has (1) a minimum market value (for example, a market value of at least 2 percent of the bank's assets), and (2) a maximum acceptable ex ante probability of default (for example, 20 basis points per year), then it is possible to limit both the probability of bank default and the expected loss on insured deposits should the bank default, thereby largely removing any safety-net funding cost subsidies that would otherwise be enjoyed by the bank. The resulting equity capital requirement is endogenously selected by the bank and can be estimated using a modified credit-VaR framework. While it is important that investors view bank subordinated debt issues as risky investments that are completely free from 
any government safety-net guarantees, this regulatory approach can be modified by increasing the magnitude of the minimum required subordinated debt issue if there is concern that subordinated debt holders benefit from "too big to fail" implicit guarantees. 2

It has long been recognized that the junior standing of subordinated debt provides a capital cushion for the deposit insurer in bank liquidation. The 1988 Basel Capital Accord includes long-term subordinated debt in a bank's Tier 2 regulatory capital measure (up to a limit of 50 percent of a bank's Tier 1 capital), ${ }^{3}$ but neither the Accord nor U.S. banking regulations currently require that a bank issue subordinated debt. Subsequent to a 1983 study by the Federal Deposit Insurance Corporation which recommended that banks be required to issue subordinated debt, a large literature has developed that investigates the potential use of bank subordinated debt as a supervisory tool, and the internal models regulatory capital proposal advanced in this paper is clearly related to this literature. ${ }^{4}$

Those advocating a mandatory subordinated debt issuance policy argue that such a requirement has the potential to exert market discipline on banking operations. A 1999 staff study by Federal Reserve Board reviews the mechanism through which this market discipline may promote bank safety and soundness. This mechanism includes: (i) subordinated debt funding costs that increase as a bank increases the riskiness of its investments thereby reducing the gains that accrue to bank equity holders; (ii) discipline exerted by bank counterparties who will monitor bank subordinated debt spreads and interpret them as a relative risk measure; and (iii) regulatory discipline if specific supervisory actions are linked (formally or informally) to debt spreads or bank issuance irregularitics.

The recommondation in this study differs from earlier subordinated debt proposals in that it includes both minimum issuance requirements and a maximum allowable probability of default at issuance. The issuance requirements are used to indirectly set minimum regulatory equity capital requirements and are not a regulation that supplements a separate regulatory capital scheme. While it is possible that a mandatory subordinated debt policy may create additional restrictions on bank management behavior through

${ }^{2}$ Studies that include Avery, Belton, and Goldberg (1998); Gorton and Santomero (1990); Flannery and Sorescu (1996); and Sironi (2001) are consistent with the hypothesis that investors may sometimes behave as if bank subordinated debt issues benefit from safety-net protections.

${ }^{3}$ This proposal would not include subordinated debt in a bank's regulatory capital measure.

4 These studies include inter alia, Benston, Eisenbeis, Horvitz, and Kaufman (1986); Horvitz (1983 and 1986); Avery, Belton, and Goldberg (1988); Keehan (1988); Cooper and Fraser (1988); Wall (1989); Gorton and Santomero (1990); Osterberg and Thomson (1991); Evanoff (1993); Hassan, Karels, and Peterson (1994); Litan and Rauch (1997); Evanoff and Wall (2000); Calomiris (1997 and 1999); Banker's Rountable (1998); and Kaufman, and others (2002). 
increased market or supervisory discipline, this is not the primary operational function of subordinated debt in this proposal; mandatory subordinate debt issuance is recommended as a practical way to implement an internal models approach for regulatory capital requirements for credit risk.

\section{The Appeal of an Internal Models approach for Capital Regulation}

Regulatory capital requirements can be used to control the moral hazard risks that arise when banks benefit from mispriced safety net guarantees. Funding cost subsidies accrue to bank shareholders when bank deposits are covered by under-priced deposit insurance schemes, or when bank funding costs are reduced by implicit "too big to fail" government guarantees. Other things equal, the magnitude of these subsidies is an increasing function of the risk of a bank's investment portfolio and the leverage gained from the guaranteed liabilities in a bank's capital structure.

The distortions created by safety net funding cost subsidies can be sufficiently strong so that banks may find it profitable to invest in social welfare-reducing risky negative net present value (NPV) investments. By controlling bank leverage, regulatory capital requirements can be used to reduce funding cost subsidies, dull bank incentives to undertake high risk investments, and thereby reduce the social welfare losses created when banks invest in negative NPV activities.

If a uniform regulatory capital requirement (a maximum leverage ratio) is set sufficiently high, it is possible to reduce the safety net related benefits that create the moral hazard incentives that distort bank investment behavior. If banks bear costs when raising external capital and have monopolistic access to at least some forms of positive NPV lending activities, excessive regulatory capital requirements can, however, reduce social welfare by limiting banks' ability to profitably fund positive NPV investments. Under a scheme of uniform regulatory capital requirements, a tradeoff arises between controlling moral hazard and limiting the social benefits associated with positive NPV lending activities as the level of regulatory capital necessary to remove safety net subsidies and forestall moral hazard is positively related to the risk of a bank's investment opportunity set. A bank with overly risky investment possibilities (a potentially bad bank) requires higher regulatory capital requirements to control moral hazard than does a bank with a relatively safe set of investment options (a potentially good bank). To be effective, uniform regulatory capital requirements must be set high enough to control the behavior of bad banks and yet this level of regulatory capital may limit the ability of good banks to make positive NPV loans. ${ }^{5}$

\footnotetext{
${ }^{5}$ Gennotte and Pyle (1991), Rochet (1992), Chan Greenbaum and Thakor (1992), Craine (1995), and Kupiec and O'Brien (1998) consider models in which banks invest in positive NPV investments. The Kupiec and O'Brien (1998) analysis includes the most
} 
By specifying bank-specific capital requirements that are linked to the risk of a bank's investment portfolio, risk-based capital requirements, in theory at least, can limit the social welfare loss that may be generated by capital regulation. Ideally, the bank-specific capital requirements generated by a risk-based system should be set so that they are large enough to remove moral hazard incentives generated by a bank's unique investment opportunity set without unnecessarily limiting a bank's ability to fund its positive NPV loan investments. ${ }^{6}$ Making this regulatory ideal operational is problematic even if banking supervisors have complete discretion in setting individual bank regulatory capital requirements (they don't). Kupiec and O'Brien (1998) show that supervisors need almost complete information about a bank's investment opportunity set in order to set bank specific capital requirements at a socially optimal level. An implication is that any practical scheme for setting risk-based capital requirements is likely to be socially suboptimal and supervisors will always be selecting among competing second best alternatives.

The 1988 Basel Accord [Basel Committee on Banking Supervision (1988)] established a uniform system for setting risk-based regulatory capital requirements for internationally active banks. The Accord's regulatory capital scheme is risk-insensitive and has encouraged bank behavior that can be construed as "regulatory arbitrage." Banks originate high quality loans to service customer relationships, securitize these loans to remove them from their balance sheets, retain the high risk first-loss tranche of the securitization structures, and reduce their regulatory capital requirement in the process. While such behavior can be explained as a process whereby "good" regulatory capitalconstrained banks free up additional funds to invest in additional positive NPV loans, it is also consistent with behavior that would be exhibited by "bad" banks that are removing high quality credits from their balance sheets to increase the risk of their portfolios and raise the capitalized value of their safety net induced funding subsidies.

The New Basel Capital Accord (NBA) [Basel Committee on Banking Supervision (2001)], first made public in January 2001, proposed significant revisions to the 1988 Accord's risk-weighed capital scheme and specifies credit risk weights that are linked either to bank internal loan classification schemes, as in the Internal Rating Based (IRB) approaches, or to external credit ratings, as in the Standardized approaches. Both approaches set credit risk weights according to a credit's anticipated probability of default and are, at least in part, designed to mimic the techniques used internally by

general investment opportunities set and focuses on how these opportunities affects the design of regulatory policy.

${ }^{6}$ While all banks may share common investment opportunities (government bonds, market-traded bonds, etc), if banks have monopoly access to some investment opportunities (for example when a banking relationship is costly to establish but adds economic value), the risk-return characteristics of bank investment opportunity sets differ and these differences complicate the design of regulatory capital policies. 
banks. In proposing the NBA, the BCBS' stated objective is to place "a greater emphasis on banks' own assessment of the risks to which they are exposed in the calculation of regulatory capital charges."

The regulatory capital schemes proposed in the NBA make capital requirements more sensitive to the credit risks in bank loan portfolios but do not allow the direct use of bank internal model estimates to set regulatory capital. In the Standardized Approaches, credit risk capital requirements are linked either to the external credit ratings of firms or to the credit rating of their sovereign. In the IRB approaches, credit risk weights are set according to a credit's anticipated probability of default. While the IRB approaches do not use bank internal models directly, the regulatory capital requirements generated under the IRB approaches are calibrated using buffer stock capital allocations estimated from industry standard credit VaR models that are applied to a stylized bank loan portfolio.

The NBA regulatory proposals generate capital requirements that are much more sensitive to risks, but they only imperfectly account for portfolio effects and are calibrated without regard to the externalities generated by bank funding cost subsidies. Analysis in Kupiec (2001b) shows that the proposed IRB approaches are not neutral with respect to bank risk taking behavior and they may create incentives for IRB banks to concentrate lending in the low risk segment of the fixed income market-a segment that has traditionally preferred bond issuance to bank finance.

The IRB regulatory capital proposals are envisioned by some as a partial step towards a regulatory structure in which banks are permitted to use their internal credit risk models for setting regulatory capital requirements for credit risk. In the early 1990's, banking interest groups successfully convinced banking regulators to allow the use of bank internal market risk measurement models as a basis for setting market risk capital requirements ${ }^{8}$ and more recently, banking associations and risk management consultancies have argued that banks should be allowed to use their internal credit risk model estimates as a basis for setting credit risk capital requirements. ${ }^{9}$ Those that advocate an internal models approach to regulation reason that the use of internal models will result in regulatory capital requirements that are more closely aligned with the socalled "economic capital" allocations set by bank managers for operational purposes, and thereby lower regulatory compliance costs and create fewer distortions in credit and securities markets.

${ }^{7}$ Basel Committee on Banking Supervision (2001), paragraph 5.

${ }^{8}$ Basel Committee on Banking Supervision (1995).

${ }^{9}$ See, inter alia, ISDA (2001), Institute of International Finance (2001), The Financial Services Roundtable (2001), or KPMG (2001). 


\section{InTERNAL MODELS AND REGULATORY OBJECTIVES}

An important issue that must be clarified before analyzing alternative approaches for setting regulatory capital is the objective function that underlies capital regulation. Credit VaR buffer stock capital allocations maximize the use of bank leverage subject to limiting the probability of default to some maximum acceptable target level. As a consequence, regulatory capital requirements that are based on credit VaR capital estimates limit the probability that a bank's resources are insufficient to honor its liabilities without public (or perhaps a cooperative insurance scheme's) support. Because these techniques ignore the losses that are generated when a bank defaults, they are not constructed to protect the value of depositor claims in bank default or minimize the cost of bank resolutions. ${ }^{10}$

If the regulator's objective is to protect the insured depositors and limit the probability of bank insolvency to some de minimus level-as seems to be the case when regulators discuss the need to limit systemic risk--then capital requirements must be designed to limit the probability that a bank's resources are insufficient to honor all of its liabilitiesinter alia, insured deposits, off balance sheet guarantees, derivatives, and subordinated debt-as well as limit the cost of protecting depositors' interests when banks fail. Standard credit VaR capital estimates are not designed to satisfy this multiple set of objectives.

In addition to issues related to regulators' primary objectives, there are extremely serious issues associated with the statistical validation of credit VaR model estimates. Kupiec (1995) discusses basic techniques that can be used for assessing the accuracy of risk measurement model estimates and analyzes the power of these statistical tests. His results, and subsequent analysis [Christofferson (1998)], show that it is mathematically impossible to statistically validate the accuracy of a bank's internal risk management models with a high degree of confidence unless the monitoring sample size is exceptionally large. Because credit-VaR model estimates are typically based on horizons of one-year, small sample sizes are unavoidable in model performance analysis.

In addition to validation issucs, internal model capital allocation techniques include important shortcomings that compromise their suitability as a basis for regulatory capital requirements. As they are typically constructed, credit VaR measures provide biased estimates of buffer stock capital requirements. In some circumstances, the bias is associated with a significantly understated probability of insolvency. Before formally analyzing the shortcomings of credit VaR capital allocations and considering modifications that may be necessary to satisfy regulatory goals, the following section will introduce the formal framework that will be used in the analysis.

${ }^{10}$ The regulatory objective of least-cost resolution is the basis for the FDICIA's prompt corrective action supervisory guidelines (12 U.S.C. $\S 18310$ ) and the guidelines that govern the U.S. FDIC's actions in insurance related activities (12 U.S.C. $\$ 1823 c(4)$ ). 


\section{Credit Risk and the Value of Safety-Net Guarantees}

\section{A. Background}

This section modifies the Merton (1977) modeling framework to formally establish the value of an implicit or explicit safety net guarantee to bank shareholders under alternative approaches for setting regulatory capital requirements for credit risk. For modeling transparency, we assume the existence of a government agency that explicitly insures the value of banks' deposit liabilities. For simplicity, it is assumed that safety net guarantees are provided at a fixed ex ante rate normalized to 0 and so the safety net guarantee is costless to the bank. ${ }^{11}$ While bank safety net funding cost benefits are modeled using a fixed rate deposit insurance structure, similar issues will arise when bank liabilities are only implicitly guaranteed under "too big" or "too important to fail" social arrangements. Following Merton (1977), the analysis does not consider information asymmetries that may arise in the context of the valuation of bank shares and assumes that the value of bank assets are transparent to equity market investors.

In order to analyze alternative internal models approaches for setting regulatory capital requirements for credit risk, it is necessary to consider the market value of stakeholder claims under an investment opportunity set that differs from the one considered in Merton (1977). While Merton (1977) restricted bank investment opportunity sets to traded equity, the analysis that follows will restrict a bank's investment opportunity set to traded risky discount bonds.

\section{B. Asset Value Dynamics}

The analysis that follows assumes that a firm's underlying assets evolve in value according to geometric Brownian motion,

$$
d A=\mu A d t+\sigma A d z
$$

where $d z$ is a standard Weiner process. If $A_{0}$ represents the initial value of the firm's assets, and $A_{T}$ the value of the firm's assets at time T, Ito's lemma implies,

$$
\ln A_{T}-\ln A_{0} \sim \phi\left[\left(\mu-\frac{\sigma^{2}}{2}\right) T, \quad \sigma \sqrt{T}\right],
$$

where $\phi[a, b]$ represents the normal density function with a mean of " $a$ " and a standard deviation of " $b$ ". Equation (2) defines the physical probability distribution for the end-ofperiod value of the firm's assets,

$$
\widetilde{A}_{T} \sim A_{0} e^{\left(\mu-\frac{\sigma^{2}}{2}\right) T+\sigma \sqrt{T} \widetilde{\varepsilon}}
$$

${ }^{11}$ As a point of comparison, it should be noted that the U.S. deposit insurance premium rate is currently 0 for well-capitalized banks. 
where $\widetilde{\varepsilon} \sim \phi[0,1]$.

When the underlying assets or claims on these assets are traded, equilibrium absence of arbitrage conditions impose restrictions on the underlying asset's Brownian motion's drift term, $\mu=r_{f}+\lambda \sigma$, where $\lambda$ is the market price of risk associated with the firm's assets. It will be useful subsequently to use this equilibrium relationship. Define $d A^{\eta}=(\mu-\lambda \sigma) A^{\eta} d t+A^{\eta} \sigma d z . d A^{\eta}$ is the "risk neutralized" geometric Brownian motion process that is used to value derivative claims after an equivalent martingale change of measure. The probability distribution of the underlying end-of-period asset values after the equivalent martingale change of measure, $\widetilde{A}_{M}^{\eta}$, is,

$$
\widetilde{A}_{T}^{\eta} \sim A_{0} e^{\left(r_{f}-\frac{\sigma^{2}}{2}\right) T+\sigma \sqrt{T} \widetilde{\varepsilon}} .
$$

\section{Deposit Insurance Value}

If the risk-free term structure is flat, and a firm issues only pure discount debt, Black and Scholes (1973) and Merton (1974) (hereafter, BSM) demonstrated that: ${ }^{12}$ (1) the value of an uninsured firm's equity is equivalent to the value of a European (Black-Scholes) call option written on the firm's underlying assets; the call option has a maturity equal to the maturity of the firm's debt and a strike price equal to the par value of the firm's debt; and (2), the market value of the uninsured firm's debt issue is equal to the market value the issue would have if it were default risk free, less the market value of a Black-Scholes put option written on the value of the firm's assets; the put option has a maturity equal to the maturity of the debt issue and strike price equal to the par value of the discount debt.

If $B_{0}$ represents the discount bond's initial equilibrium market value, and $P a r$ represents its promised payment at maturity date $M$, the BSM model requires,

$$
B_{0}=\operatorname{Par} e^{-r_{f} M}-\operatorname{Put}\left(A_{0}, \operatorname{Par}, M, \sigma\right),
$$

where $r_{f}$ represents the risk free rate and $\operatorname{Put}\left(A_{0}, \operatorname{Par}, M, \sigma\right)$ represents the equilibrium value of a Black-Scholes put option on an asset with an initial value of $A_{0}$, a strike price of $P a r$, a maturity of $M$, and an instantaneous return volatility of $\sigma$.

The default (put) option's value in expression (5) is a measure of the credit risk of the bond. The larger the bond's credit risk, the greater the discount in its market value relative to a default riskless discount bond with identical par value and maturity.

${ }^{12}$ Other assumptions include the absence of taxes and transaction costs, the possibility of short sales and continuous trading, the assumption that investors in asset markets act as perfect competitors, and the firm's assets evolve in value following geometric Brownian motion. 
Assume that the bank can issue discount debt claims that are insured by the government. If the bank's debt is insured, its initial equilibrium market value is $\operatorname{Par}^{-r_{f} M}$ as investors require only the risk free rate of return on the debt issue. If the deposit insurer does not charge for insurance, the initial market value of the bank's equity is given by

$\operatorname{Call}\left(A_{0}, \operatorname{Par}, M, \sigma\right)+\operatorname{Put}\left(A_{0}, \operatorname{Par}, M, \sigma\right)$, where $\operatorname{Call}\left(A_{0}, \operatorname{Par}, M, \sigma\right)$ represents the value of a Black-Scholes call option on an asset with an initial value of $A_{0}$, a strike price of $P a r$, a maturity of $M$, and an instantaneous return volatility of $\sigma$. The provision of costless deposit insurance provides the bank's shareholders with an interest subsidy on the bank's debt. This interest subsidy has an initial market value equal to $\operatorname{Put}\left(A_{0}, \operatorname{Par}, M, \sigma\right)$. $^{13}$

Absent any regulatory constraints or bank franchise value, it is well known that the bank shareholders maximize the ex ante value of their wealth by maximizing the present market value of the interest subsidy on their debt, or equivalently by maximizing the value of $\operatorname{Put}\left(A_{0}, P a r, M, \sigma\right)$. By selecting the bank's investment assets and capital structure, the bank's shareholders maximize the value of their insurance guarantee by maximizing the credit risk of the insured debt claims issued by the bank.

The ex ante value of a deposit insurance guarantee was derived by Merton (1977) in the context of a bank that purchased assets that evolve in value according to geometric Brownian motion or equity type investments. As a consequence, the Merton (1977) results do not characterize the deposit insurance value enjoyed by the shareholders of a bank that invests in risky fixed income investments where the payoffs in favorable return states are limited by loan contracting terms. Using the intuition of the Merton results, it is straight-forward to derive deposit insurance values when banks invest in fixed income assets. In the absence of an insurance premium, the deposit insurance value is equal to the value of the implied default option on the bank's insured debt.

\section{Insurance Value and Risky Discount Bond Investments}

Assume that the bank can only invest in BSM risky discount bonds and that it funds these investments with equity and its own discount debt issue. Moreover, assume that the bank's investment opportunity set is restricted to discount bonds that are matched in maturity to the discount debt that the bank issues. The initial market value of the bank's bond investment is given by,

$$
B_{0}=\operatorname{Par}_{P} e^{-r_{f} M}-\operatorname{Put}\left(A_{0}, \operatorname{Par}_{P}, M, \sigma\right),
$$

${ }^{13}$ If the insurer were to charge an ex ante fee for insurance coverage, the market value of the insurance subsidy would be given by $\operatorname{Put}\left(A_{0}, \operatorname{Par}, M, \sigma\right)$ less the ex ante fee. 
where $\operatorname{Par}_{P}$ represents the par value of the purchased discount bond.

Define $\operatorname{Par}_{F}$ to be the par value of the discount bond that the bank issues to fund the bond purchase. In the absence of an insurance guarantee, if the maturity of the bank's funding debt matches the maturity of the firm's asset (both equal to $M$ ), then the end-ofperiod cash flows that accrue to the bank's debt holders are given by,

$$
\operatorname{Min}\left[\operatorname{Min}\left(\widetilde{A}_{M}, \operatorname{Par}_{P}\right), \operatorname{Par}_{F^{*}}\right] \text {. }
$$

The initial market value of the funding debt is given by discounting (at the risk free rate) the expected value of (7) taken with respect to the equivalent martingale probability distribution of the end-of-period asset's value, $\widetilde{A}_{M}^{\eta}{ }^{14}$,

$$
E^{\eta}\left[\operatorname{Min}\left[\operatorname{Min}\left(\widetilde{A}_{M}, \operatorname{Par}_{P}\right), \operatorname{Par}_{F}\right]\right] e^{-r_{f} M},
$$

where $E^{\eta}[\cdot]$ represents the expectations operator with respect to the probability density of $\widetilde{A}_{M}^{\prime \prime}$.

Applying the intuition of Merton (1977), if the bank's funding debt is costlessly guaranteed by the government, the value of the insurance guarantee that accrues to bank shareholder' is given by,

$$
\operatorname{Par}_{F} e^{-r_{j} M}-E^{\eta}\left[\operatorname{Min}\left[\operatorname{Min}\left(\widetilde{A}_{M}, \operatorname{Par}_{P}\right), \operatorname{Par}_{F}\right]\right] e^{-r_{f} M} .
$$

Alternatively, when the bank can buy long-term BSM bonds, Kupiec (2002c) shows that when the bank's funding debt is of a shorter maturity $(T)$ than the discount bond purchased by the bank (maturity $M, T<M$ ), the ex ante value of the deposit insurance guarantee is given by,

$$
\operatorname{Par}_{F} e^{-r_{F} T}-E^{\eta}\left[\operatorname{Min} \mid\left(\operatorname{Par}_{P} e^{-r_{f}(M-T)}-\operatorname{Put}\left(\tilde{A}_{T}, \operatorname{Par}_{P}, M-T, \sigma\right)\right), \operatorname{Par}_{F} \| e^{-r_{f} T} .\right.
$$

\section{Credit Var and Buffer Stock Capital allocation}

\section{A. The Credit VaR Unexpected Loss Approach}

VaR is commonly defined to be the loss amount that could be exceeded by at most a maximum percentage of all potential future value realizations at the end of a given time horizon. ${ }^{15}$ Under this definition, VaR is determined by a specific left-hand critical value of a potential profit and loss distribution, and by a right boundary against which the loss is measured. In the credit risk setting, it is common to set the right-hand boundary of the

${ }^{14}$ Alternatively, Geske (1977 and 1979) provides a closed form expression for the value of the compound option.

${ }^{15}$ This definition can be found inter alia in Duffie and Pan (1997), Hull and White (1998), Jorion (1995 and 1997), Beder (1995), and Marshall and Siegel (1997). 
VaR measure equal to the expected value of the asset's end-of-period value distribution where this VaR measure is said to estimate so-called "unexpected credit loss."

According to a BCBS survey (1999), credit VaR unexpected loss estimates are commonly used by banks to set bank internal "economic capital" allocations for credit risk and the BCBS seem to accept the propriety of this approach. Similar to the internal models regulatory approach for market risk BCBS (1995), an internal models approach for setting regulatory capital requirements for credit risk would presumably take the form of: (1) qualitative standards for credit VaR model construction and requirements for their internal use; and (2) a regulatory standard that sets a maximum threshold (the implied maximum default rate) that banks could use when calculating their internal models regulatory capital requirement.

\section{B. The Bias in Unexpected Loss Measures of Capital}

A buffer stock capital allocation is the equity portion of a funding mix that can be used to finance an asset or portfolio in a way that maximizes the use of debt finance subject to limiting the ex ante a probability of default on the funding debt to some maximum acceptable rate. ${ }^{16}$ When calculating credit VaR for buffer stock capital purposes, the credit VaR horizon implicitly equals the maturity of the funding debt issue whose target insolvency rate is being sct in the capital allocation exercise. It is only at maturity that the mark-to-market (MTM) value of the bank's liabilities can be ignored in a buffer stock capital calculation. Technical insolvency occurs when the market value of the bank's liabilities exceed the market value of the bank's assets. When the VaR horizon is identical to the maturity of the bank's funding debt, the funding debt's market value in non-default states is its par value. ${ }^{17}$

Consider the use of a 1 percent, one-year VaR measure to determine the necessary amount of equity funding for an investment under a buffer stock approach for capital. Kupiec (1999) demonstrates the importance of measuring VaR relative to the initial market value of the asset or portfolio that is being funded. If $\mathrm{VaR}$ is mcasurce relative to the asset or portfolio's initial value, by definition, there is less than a 1 percent probability that the asset's value will ever post a loss that exceeds its 1 percent VaR risk exposure measure. That is, if the firm chooses an amount of equity finance equal to its 1 percent VaR, the implication is that there is less than a 1 percent chance that any loss in

${ }^{16}$ We make no claim that this objective function formally defines a firm's optimal capital structure-indeed it almost certainly does not. It is, however, the objective function that is consistent with VaR-based capital allocation schemes and an approach commonly taken by banks according to the Basel Committee on Banking Supervision's (1999) survey results.

${ }^{17}$ Prior to the maturity of the funding debt, in addition to valuing the bank's assets, the determination of technical insolvency requires an estimate of the market value of the funding liabilities. 
its underlying assets' values will ever exceed the value of the firm's equity. A common but flawed interpretation is that this equity-financing share will ensure that there is at most a 1 percent chance that the firm will default on its debt.

Assume that VaR is measured from the asset's initial market value and that the VaR measure is completely accurate in this sense that there is no statistical error in measuring the asset's end-of-period market value distribution. In the case of discount debt or a simple bank loan, $\mathrm{VaR}$ can never exceed $V_{0}$, the initial market value of the investment. If the firm were to set the share of equity funding equal to the asset's 1 percent $\mathrm{VaR}$ measure, $\operatorname{VaR}(.01)$, the amount of debt finance required to fund the asset would be $V_{0}-\operatorname{VaR}(.01)$. If the firm borrows $V_{0}-\operatorname{VaR}(.01)$, it must pay back more than $V_{0}-\operatorname{VaR}(.01)$ if it is to avoid default. The simple intuition that underlies the VaR approach for capital allocation ignores the interest payment that must be made on funding debt. An unbiased buffer stock capital allocation rule is to set equity capital equal to 1 percent VaR (calculated from the portfolio's initial market value) plus the interest that accrues on the funding debt over the VaR horizon. ${ }^{18}$

In contrast to the capital allocation procedures described above, typical discussions of credit risk capital allocation define $\mathrm{VaR}$ as the difference between the expected value of the end-of-period asset (portfolio) value distribution and the selected critical tail value associated with a target default rate. The difference between the mean end-of-period value and the portfolio's initial value substitutes for the interest payments that must be added to a properly constructed $\mathrm{VaR}$ measure. This increment, however, does not accurately estimate the equilibrium interest payments required by the funding debt holders, and depending on the characteristics of the purchased asset and the relative maturity of the funding debt, this increment may overestimate or seriously underestimate required interest payments on funding debt.

\section{Calculating an Unbiased Buffer Stock Capital Estimate}

Consider the buffer stock capital allocation that is required in the absence of deposit insurance to limit the technical insolvency rate to $\alpha$ in the case of a held-to-maturity (HTM) (and funded-to-maturity) BSM risky discount bond.

At maturity, the payoff of the firm's purchased bond is given by, $\operatorname{Min}\left[\operatorname{Par}_{P}, \tilde{A}_{M}\right]$. The credit VaR measure appropriate for credit risk capital allocation is given by,

${ }^{18}$ Kupiec (2002a) formally establishes that the credit VaR unexpected loss metric is not a measure of credit risk, nor does it provide an unbiased benchmark for setting buffer stock credit risk capital allocations. 


$$
\operatorname{VaR}_{\text {Credit }}(\alpha)=B_{0}-\operatorname{Min}\left[\operatorname{Par}_{P}, A_{0} e^{\left[\mu-\frac{\sigma^{2}}{2}\right] M+\sigma \sqrt{M} \Phi^{-1}(\alpha)}\right],
$$

where $B_{0}$ is the initial market value of the purchased discount debt given by expression (6), and $\alpha$ is the target default rate on the funding debt. If $\alpha$ is sufficiently small (which will be assumed), the expression $\operatorname{Min}\left[\operatorname{Par}_{P}, A_{0} e^{\left[\mu-\frac{\sigma^{2}}{2}\right] M+\sigma \sqrt{M} \Phi^{-1}(\alpha)}\right]$ simplifies to $A_{0} e^{\left[\mu-\frac{\sigma^{2}}{2}\right] M+\sigma \sqrt{M} \Phi^{-1}(\alpha)}$, and consequently, the expression for credit VaR is,

$$
V_{\text {Credit }}(\alpha, M, M)=B_{0}-A_{0} e^{\left[\mu-\frac{\sigma^{2}}{2}\right] M+\sigma \sqrt{M} \Phi^{-1}(\alpha)} .
$$

In order to maintain notational consistency with the expression for a so-called mark-tomarket (MTM) credit VaR calculation (provided below), the notation for HTM credit $\mathrm{VaR}$ is defined to include three arguments: the target default rate $\alpha$, the maturity of the funding debt issue, $M$ (the second argument), and the maturity of the credit risky asset, $M$.

$B_{0}-V a R_{C r e d i i}(\alpha, M, M)=A_{0} e^{\left[\mu-\frac{\sigma^{2}}{2}\right] M+\sigma \sqrt{M} \Phi^{-1}(\alpha)}$ determines the maximum par value of the funding debt that is consistent with the target default rate. The initial market value of this funding debt issue is given by,

$$
E^{\eta}\left[\operatorname{Min}\left[\operatorname{Min}\left(\widetilde{A}_{M}, \operatorname{Par}_{P}\right), A_{0} e^{\left[\mu-\frac{\sigma^{2}}{2}\right] M+\sigma \sqrt{M} \Phi^{-1}(\alpha)}\right]\right] e^{-r_{f} M} .
$$

These relationships define the equilibrium required interest payment on the funding debt,

$$
A_{0} e^{\left[\mu-\frac{\sigma^{2}}{2}\right] M+\sigma \sqrt{M} \Phi^{-1}(\alpha)}-E^{\eta}\left[\operatorname{Min}\left[\operatorname{Min}\left(\tilde{A}_{M}, \operatorname{Par}_{P}\right), A_{0} e^{\left[\mu-\frac{\sigma^{2}}{2}\right] M+\sigma \sqrt{M} \Phi^{-1}(\alpha)}\right]\right] e^{-r_{f} M} .
$$

Expressions (12) and (14) imply that the initial equity allocation consistent with the target default rate $\alpha$ is given by,

$$
B_{0}-E^{\eta}\left[\operatorname{Min}\left[\operatorname{Min}\left(\widetilde{A}_{M}, \operatorname{Par}_{p}\right), A_{0} e^{\left[\mu-\frac{\sigma^{2}}{2}\right] M+\sigma \sqrt{M} \Phi^{-1}(\alpha)}\right]\right] e^{-r_{F} M} .
$$

When the maturity of the purchased credit is greater than the maturity of the funding debt, the probability distribution for the end-of-period value of the credit is generated by estimating the credit's future MTM value as the value of its supporting assets vary 
according to their probabilistic laws of motion [expression (3)]. In the MTM credit VaR setting, when the maturity of the credit $(M)$ exceeds the maturity of the funding issue $(T)$, Kupiec (2002c) shows that the initial equity capital allocation consistent with a target default rate $\alpha$ is given by,

$$
B_{0}-E^{\eta} \mid \operatorname{Min}\left\lfloor\left(\operatorname{Par}_{P} e^{-r_{f}(M-T)}-\operatorname{Put}\left(\tilde{A}_{T}, \operatorname{Par}_{P}, M-T, \sigma\right)\right), \operatorname{Par}_{F}(\alpha, T, M) \| e^{-r_{f} T} .\right.
$$

\section{Safety Net Externalities and Internal Models Capital Estimates}

A simple buffer stock capital allocation, even if it is completely accurate, does not remove the risk of default. If equity capital is set according to a buffer stock capital rule, and the target solvency rate is positive, there is some chance the firm will default on its liabilities. If the firm happens to be a bank, the bank's resources in default may be insufficient to repay the bank's depositors.

When safety nets are valuable to banks, other problems are introduced into the internal models capital allocation process. If investors view insured bank liabilities as if they are riskless, the initial market value of bank claims will increase relative to identical claims issued by a non-insured entity. That is, for any given par value of a discount liability offered to investors by a bank, the initial market value of the discount issue will be greater if investors treat the claim as if it is insured. The reduction in interest expense engendered by the safety net guarantee allows bank shareholders to invest less equity (compared to a non-insured business) in order to establish a given target rate for insolvency. In other words, given two banks that are identical in all respects except that one is (costlessly) insured and the other is not, the insured bank's shareholder will be required to invest less in order to achieve a given insolvency rate.

Suppose a regulatory authority mandates that an insured bank has sufficient capital so that at the end of some specific horizon, the bank remains technically solvent in at least $100 *(1-\alpha)$ percent of all outcomes. If the insured bank takes into account the safety net related interest subsidy in its internal capital allocations, it can meet the regulatory mandated target solvency rate with less equity capital than would be required by an otherwise identical non-insured institution. The reduction in the buffer stock equity capital requirement is equal to the reduction in the interest cost on the bank's debt.

In the case of HTM buffer stock capital requirements for credit risk, Kupiec (2002c) shows that the interest subsidy on the bank's debt is given by,

$$
A_{0} e^{\left[\mu-\frac{\sigma^{2}}{2}\right] M+\sigma \sqrt{M} \Phi^{-1}(\alpha)-r_{f} M}-E^{\eta}\left[\operatorname{Min}\left[\operatorname{Min}\left(\widetilde{A}_{M}, \operatorname{Par}_{P}\right), A_{0} e^{\left[\mu-\frac{\sigma^{2}}{2}\right] M+\sigma \sqrt{M} \Phi^{-1}(\alpha)}\right]\right] e^{-r_{f} M},
$$

where $M$ is the maturity of the fixed income asset, the funding debt, and the VaR horizon. The interest subsidy is identical to the deposit insurance guarantee value 
(expression(9)) evaluated at the par value of funding debt set by the regulatory determined minimum solvency rate, $\operatorname{Par}_{F}=A_{0} e^{\left[\mu-\frac{\sigma^{2}}{2}\right] M+\sigma \sqrt{M} \Phi^{-1}(\alpha)}$.

In a MTM credit risk setting, where the bank's funding debt has a maturity of $T$, and the fixed income asset that is purchased by the bank has a par value of $\operatorname{Par}_{P}$, a maturity of $M, T<M$, and the VaR horizon is $T$, Kupiec (2002c) shows that the interest subsidy is given by,

$$
\operatorname{Par}_{F}(\alpha, T, M) e^{-r_{f} T}-E^{\eta} \mid \operatorname{Min}\left\|\left(\operatorname{Par}_{P} e^{-r_{f}(M-r)}-P u t\left(\tilde{A}_{T}, \operatorname{Par}_{P}, M-T, \sigma\right)\right), \operatorname{Par} F(\alpha, T, M)\right\| e^{-r_{f} T},
$$

where $\operatorname{Par}_{F}(\alpha, T, M)$ is the par value of the bank's funding debt set by the buffer stock capital calculations,

$$
\operatorname{Par}_{F}(\alpha, T, M)=\operatorname{Par}_{P} e^{-r_{f}(M-T)}-P u t\left(A_{0} e^{\left[\mu-\frac{\sigma^{2}}{2}\right] T+\sigma \sqrt{T} \Phi^{-1}(\alpha)}, \operatorname{Par}_{P}, M-T, \sigma\right) .
$$

Expression (18) is identical to expression (10) evaluated at the par value for the bank's funding debt that satisfies the regulatory internal models solvency requirement, and as such, it represents the ex ante value of the insurance guarantee to the bank's shareholders under an internal models approach for regulatory capital. Expressions (17) and (18) represent the deposit insurance values that a bank generates under internal model approaches for setting regulatory capital requirements for credit risk. The insurance subsidy is not uniform; its value can be altered by altering the risk characteristics of the equity or the discount bond in which the bank invests. Consequently, an internal models approach to setting regulatory capital may stimulate banks' demand for investments that offer attractive insurance subsidy benefits.

If equity markets are competitive and there are no asymmetric information costs associated with new equity issuance, existing bank shareholders will be able to capture the safety net subsidies associated with all new investments, and the existing shareholders will maximize their wealth by raising new equity capital and investing in all fair-valued investments that generate a positive safety net funding subsidy. If, however, there are costs associated with issuing new bank shares, existing bank shareholders will not capture the full value of the safety net funding subsidy and shareholders may not find it optimal to exploit all fair-valued investments with positive safety net subsidies. Instead, when raising outside bank equity capital is costly, the shareholder maximization problem must recognize the tradeoffs between the costs required to raise outside equity and the corresponding benefits that can be attained from exploiting available safety net guarantees. In the extreme case in which outside equity issuance costs are prohibitive, existing shareholders will allocate their equity capital across investments in order to maximize the value of the insurance subsidy per dollar of equity invested. 


\section{Figure 1: Insurance Value Under a HTM Internal Model Capital Requirement}

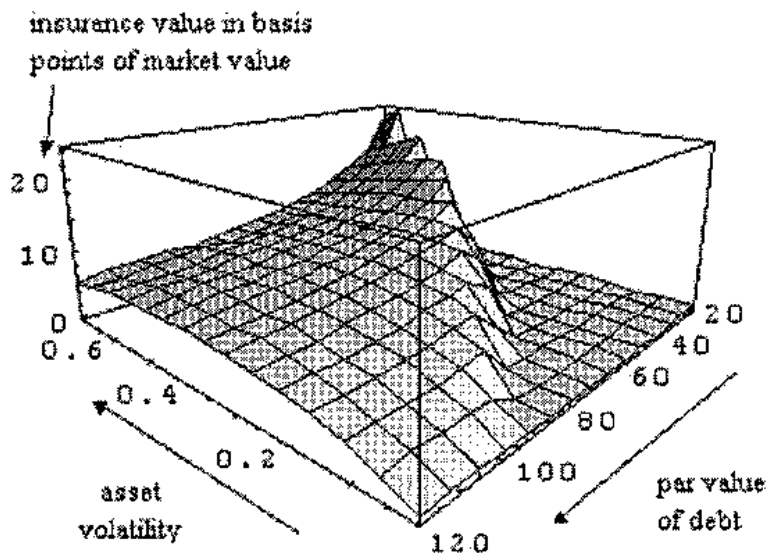

Consider the insurance value generated under an internal models approach to regulatory capital for credit risk when the maturity of the assets are identical to the maturity of the insured bank liabilities and both have a maturity of one-year. In this HTM case, the value of the safety net subsidy generated under an internal models approach to credit risk capital (given by expression (17)) depends on specific characteristics of the purchased bonds, including the bond's par value, the market value of the bond's supporting assets, their return volatility, and the market price of risk.

The insurance value surface generated under a one-year, 1 percent internal models capital requirement for the one-year discount bonds is plotted in Figure 1 under the assumption that the supporting assets have an initial market value of 100 , the market price of risk is 10 percent and the risk free rate is 5 percent. In this example taken from Kupiec (2002c), credit risk is declining in the bond's par value and volatility, so the bonds in the northeast quadrant of the figure have the smallest credit risks. The peak of the insurance value surface corresponds to a set of discount bonds that have only modest credit risk as, under a 1 percent internal model capital constraint, these bonds allow the bank to use considerable funding leverage.

Figure 2, also taken from Kupiec (2002c), plots the insurance value surface pictured in Figure 1 when insurance value is measured in basis points per dollar of required equity capital - the insurance value measure that is relevant for the shareholders of a capitalconstrained bank. The face of the cliff in Figure 2 corresponds with the peak of the mountain ridge in Figure 1. The high plateau at the top of the cliff corresponds with the bonds in Figure 1 that populate the minimal credit risk "lowlands" in the northeast triangle-shaped region of Figure 1. Under the 1-percent internal models capital requirement, the bonds in this region - bonds with minimal credit risk - can be fully financed with insured deposits. Since bank shareholders make no investment but accrue fully the credit risk premium paid by these bonds (however small), the bonds on the plateau above the cliff face in Figure 2 represent a pure arbitrage from the perspective of a bank's shareholders. 
Figure 2: Insuratce Value in Basis Pounts of Required Equity Capital

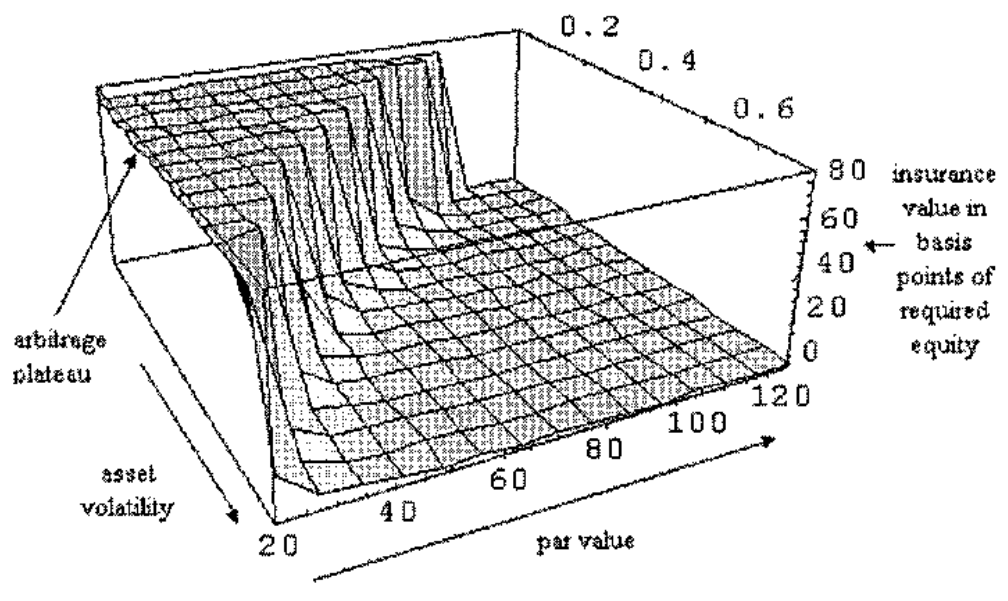

The insurance values and investment biases generated in the MTM internal models case are qualitatively similar to those generated in Figures 1 and 2 for the HTM internal models capital calculations. The interested reader is referred to Kupiec (2002c) for further details.

\section{USing Subordinated DebT to IMPLEMENT an InTERnal Models CaPital REgulation}

\section{A. Requirements on Subordinated Debt}

Many of the shortcomings inherent in an internal models approach for setting regulatory capital for credit risk can be mitigated if the underlying prudential requirements are modified only slightly, but are re-expressed in a way that may at first seem unrelated to an internal models approach to capital regulation. If a bank is required to fund its credit risky assets with a minimum amount of subordinated debt that is free from safety net protections, and this subordinated debt is required to have, at issuance, a maximum probability of default, then it is possible to both limit the probability of bank insolvency and control the expected losses on the bank's guaranteed liabilities should the bank default. Under this approach to setting regulatory capital, the bank can use its internal credit VaR models to estimate its equity capital and subordinated debt issuance requirements, and supervisors can use subordinated debt market values, agency ratings, and yield spreads as supplemental information when they attempt to verify the accuracy of bank internal models estimates.

Consider the following concrete example. Assume that regulations require a bank to fund its assets, in part, with a subordinated debt issue that must at issuance, have a market value that is at least 2 percent of the value of the bank's assets and may not have a probability of default that exceeds 20 basis points in its first year. The latter condition 
basically requires that the bank's subordinated debt be rated as "investment grade" when it is issued. For simplicity, the analysis will focus on a one-year regulatory horizon and so the subordinated debt will carry a maturity of one-year and all bank internal model estimates will be based on a one-year horizon. While appearance may suggest otherwise, this subordinated debt issuance requirement actually determines a bank's regulatory capital requirement for shareholder's equity. This form of an equity regulatory capital requirement includes both a buffer stock solvency constraint, and an implicit constraint that attenuates the safety net insurer's losses should a bank default.

\section{B. Using Subordinated Debt and Internal Models to Set Equity Capital Requirements}

A bank is technically insolvent when the market value of its existing assets are insufficient to discharge its liabilities when they mature. When the bank issues both insured deposits and subordinated debt, the maturity values of both claims must be taken into account when calculating internal model buffer stock capital allocations.

Recall that, when calculating an internal model buffer stock capital requirement in the simple case (single seniority class of debt), the critical value of the end-of-period probability distribution for the asset's value that is consistent with the target (maximum acceptable) insolvency rate determines the maximum par value of debt that can be issued by the bank. When the bank issues both insured deposits and subordinated debt, this critical asset value determines the total debt related payments that can be promised by the bank and remain within the required solvency rate margin.

Consider the case where the bank's credit has a maturity identical to that of the subordinated debt issue (one-year). Let D represent the initial value of the guaranteed liabilities that the bank accepts (assumed to be discount instruments) and $P_{F}$ represent the par value of the risky subordinated debt that is issued by the bank. The solvency rate restriction on the bank's subordinated debt issue requires,

$$
P_{F} \leq \operatorname{Min}\left[\operatorname{Par}_{P}, A_{0} e^{\left[\mu-\frac{\sigma^{2}}{2}\right] M+\sigma \sqrt{M} \Phi^{-1}(\alpha)}\right]-D e^{r_{f}},
$$

where the equality will hold when the bank faces incentives to maximize the use of leverage as will typically be the case if safety nets are valuable. ${ }^{19}$

Expression (19) shows that, given the risks in a banks investment portfolio, the use of insured deposits restricts a bank's ability to issue subordinated debt. Similar to a buffer stock equity capital rule, expression (19) does not control the potential losses associated

${ }^{19}$ When the bank invests in risky debt, it will be assumed that $\alpha$ is sufficiently small so that $\operatorname{Par}_{P}>A_{0} e^{\left[\mu-\frac{\sigma^{2}}{2}\right] M+\sigma \sqrt{M} \Phi^{-1}(\alpha)}$. 
with a bank default as the bank could set the par value of subordinated debt at a de minimus amount, say .01, issue subordinated debt, and satisfy the default rate condition. In this example, while subordinated debt holders would bear the first losses when the bank defaults, the depth of the losses they absorb in default would be trivial, and default losses are borne primarily by the bank deposit insurer. In this case, when the bank's assets fall in value to $A_{0} e^{\left[\mu-\frac{\sigma^{2}}{2}\right] M+\sigma \sqrt{M} \Phi^{-1}(\alpha)}$, the subordinated debt holders become the bank's owners, but should the assets fall in value by just a penny more, the insured depositors become the owners and bear losses if a third party insurer does not assume control, bear the losses, and pay the insured depositors their promised terminal payouts.

While payoffs on all bank liabilities may be triggered by a default on its most junior obligation, in some instances of default, bank depositors may be paid in full even in the absence of a safety net guarantee. The ex ante probability that depositors (or more correctly, their third party insurer) bear losses in default depends on both the ex ante probability of default on the bank's subordinated debt and the initial market value of the bank's subordinated debt issue. Given the probability of default on the subordinated issue, the larger is its initial market value, the smaller is the probability that the deposit insurer will bear losses.

In the case of one-year subordinated debt, with $P_{F}<P_{P}$, the initial market value of the subordinated debt is given by,

$$
\left.E^{\eta}|\operatorname{Max}| \operatorname{Min}\left(\tilde{A}_{1}-D e^{r_{f}}, \operatorname{Par}_{F}\right), 0\right] \mid e^{-r_{f} M} \text {. }
$$

Assuming the leverage constraint on the bank's probability of insolvency is binding (i.e., expression (19) holds as an equality)), expression (20) indicates that, in order for the bank to increase the market value of its subordinated debt issue, it must increase the par value of the issue and decrease the amount of insured deposits it accepts. Increasing the regulatory capital requirement "lever" that controls the minimum acceptable market value of the subordinated debt issue (holding constant its probability of default) is in essence a requirement that subordinated holders assume ownership (and bear losses) over a larger range of the bank's asset credit-loss distribution. The market value restriction controls the size of the "wedge" between the probability that the bank is insolvent, and the probability that the deposit insurer bears losses. The larger the required market value of subordinated debt, the larger is this wedge, and the smaller is the probability that the deposit insurer bears losses.

When the regulatory capital requirement on the market value of the bank's subordinated is a minimum proportion, $\beta$, of the bank's asset value, the capital requirement can be formally written,

$$
E^{\eta}|\operatorname{Max}| \operatorname{Min}\left(\tilde{A}_{1}-D e^{r_{f}}, \operatorname{Par}_{F}\right), 0 \| e^{-r_{f} M} \geq \beta A_{0}
$$


It should be noted that the market value of the bank's subordinated debt and the value of the bank's assets (the book value at least) are observable quantities and so verification issues are diminished over those that arise in a simple internal models approach. While valuing bank loans may not be a trivial exercise without difficult complications, if banks are optimistic in their loan loss provisions and overstate loan values, they will be required to issue subordinated debt with greater market value ${ }^{20}$ The regulatory risks associated with over-optimistic bank loan valuations are in part attenuated by the requirement of a larger subordinated issue and thus a larger buffer for the deposit insurer. ${ }^{21}$

The bank will set its equity capital requirement by using its credit VaR models to estimate the critical value on its asset portfolio's future value distribution. In the case of the BSM discount bond examples used in this analysis, the critical value is given by, is, $A_{0} e^{\left[\mu-\frac{\sigma^{2}}{2}\right] M+\sigma \sqrt{M} \Phi^{-1}(\alpha)}$. Since it is in the bank shareholder's interest to maximize the use of guaranteed (funding cost subsidized) deposits, the bank will optimize its capital structure by choosing, simultaneously, the smallest value of $P_{F}$ and the largest value of $D$ that satisfy expressions (19) and (21). While the analysis has focused on the case in which the bank's investments and liabilities are maturity-matched, the extension to the MTM case, when the bank's investments have longer maturities than its liabilities, is straightforward and omitted for sake of brevity.

It should also be recognized that the analysis has assumed that subordinated debt investors price these liabilities as if they will bear full default losses without any benefit from the intervention of a safety net provider. If systemic risk concerns are sufficiently strong, and safety nets are perceived to be sufficiently broad, subordinated debt investors may behave as if safety net benefits may, in some circumstances, be extended to subordinated debt holders. ${ }^{22}$ In this case, subordinated debt values are increased above their uninsured fair market values and their initial market value is no longer an accurate indicator of the degree of protection that subordinated debt will offer to the deposit insurer in the case of default. If this issue is judged to important because of empirical evidence or historical precedent, the regulatory requirement for the minimum value of the

${ }^{20}$ A full discussion of the specific operational and institutional details associated with implementation of the proposed approach, including its generalization to a dynamic setting, is beyond the scope of this paper. The difficulties associated with valuing bank assets and the differences between book and market valuations are discussed, for example, in Berger and Davies (1998) and Berger, Flannery, and Davies (2000).

${ }^{21}$ In this approach, loan-loss provisions should represent the difference between the book value of loans and an estimate of their fair market value. Loan-loss provisions that reduce the book value of loans reduce equity capital and are not a component of the regulatory capital measure proposed in this paper.

${ }^{22}$ See footnote 2. 
subordinated debt issue can be increased to compensate for the safety net engendered valuation bias in subordinated debt market value.

The probability associated with the critical value in the credit VaR calculation represents the probability of default on the most junior debt issue-in this case the bank's subordinated debt. If, in addition to the quantitative requirement on the solvency rate on subordinated debt, a qualitative requirement was added that required the subordinated debt issue to be rated by an independent rating agency, the ratings would provide an indirect way (imperfect no doubt) to evaluate the probability of default on the subordinated debt issue that could supplement the direct examination verification procedures adopted by supervisors.

\section{Examples}

Consider a specific example of the subordinated debt approach for implementing an internal models regulatory capital requirement for credit risk. Assume that regulations require that one-year subordinated debt be used to finance 2 percent of the value of the bank's assets and that the subordinated debt must have a probability of default that is less than 20 basis points. Assume that the bank's investment opportunity set includes only BSM risky discount bonds. For simplicity assume all these bonds have underlying assets with an initial market value of 100 , a market price of risk of 5 percent, and par values of 108. Credit risk is varied in this example by varying the volatility of these bond's supporting assets' values. The greater the volatility, the greater the credit risk of the BSM bond.

Table 1 reports on the efficacy of this capital regulation when banks are restricted to purchasing one-year BSM discount bonds. The first four columns of Table 1 report on the market value and risk characteristics of the purchased bond. Columns 5-8 of the table report on various quantities that are needed to calculate the bank's implied equity capital requirement. Columns 9-10 report the equity capital requirement in alternative basis, and the final two columns of the table report on the value of the safety net guarantee appropriated by bank shareholders.

The results reported in Table 1 indicate that the proposed approach for setting regulatory capital requirements, even under the modest regulatory limits of the example, produces a risk-based regulatory capital requirement that: (1) almost completely removes the safety net funding cost subsidy; and (2) allows banks to generate very little variation in the funding cost subsidy by varying the credit risk of its assets. While the example does show that funding cost subsidies may rise slightly as asset credit risk is increased, the subsidy remains below $1 / 2$ a basis point of asset value in all cases considered, and these cases include alternatives with substantial credit risk. Not only are these subsidies small and likely to be insignificant compared to real world uncertainties and transactions costs, they can be further decreased either by decreasing the regulatory minimum probability of default or by increasing the required share of subordinated debt funding. 
Table 2 repeats the analysis of Table 1, but restricts the bank's investment opportunities to three-year BSM risky discount bonds. This example illustrates the use of the procedures in the MTM VaR setting which were omitted from the discussion in the prior section. The results in Table 2 are completely consistent with those reported in Table 1. Again they show that as credit risk is increased to very high levels, the safety net subsidy value can be increased, but even in the highest risk cases the attainable safety net values remain trivial.

\section{Conclusions}

Proposals that advocate the use of bank internal buffer stock capital allocation models to set regulatory capital requirements overlook important flaws in bank capital allocation practices and ignore the importance of externalities generated by the safety net funding cost subsidies enjoyed by banks. Credit VaR unexpected loss estimates produce biased estimates of buffer stock capital requirements. Unbiased buffer stock capital estimation requires the recognition of the interest costs on funding debt. When banks enjoy a funding cost subsidy because of implicit or explicit safety net guarantees on their liabilities, they will produce downward biased internal model estimates of "economic capital" that will, if used to set regulatory capital, ensure that bank shareholders earn safety net engendered profits. Because the internal models capital bias is not uniform with respect to the risk profiles of alternative investments, a simple internal models approach for setting credit risk capital requirements will distort bank investment incentives.

It is possible to remove many of the shortcomings of the internal models approach for credit risk capital regulation by reformulating the way that capital regulation is implemented. If a bank is required to issue subordinated debt in addition to its senior insured liabilities, it is demonstrated that if regulatory capital requirements are specified in terms of: (1) a requirement that a bank fund its activities with a subordinated debt issue of a minimum market value; and (2) a maximum acceptable ex ante probability of default on a bank's subordinated debt issue, then it is possible to limit both the probability of bank default and the expected loss on insured deposits should the bank default, and thereby largely remove any safety net funding costs subsidies that would otherwise be enjoyed by a bank. The resulting equity capital requirement is endogenously selected by the bank and can be estimated using a modified credit-VaR framework. Any remaining safety net subsidies can be made arbitrarily small by altering the regulatory subordinated debt issuance requirements, and banks have only a limited ability to vary the subsidy by varying the risk characteristics of their investment portfolio. 
Table 1. Regulatory Capital Requirements for Maturity-Matched Debt

\begin{tabular}{|c|c|c|c|c|c|c|c|c|c|c|c|c|}
\hline $\begin{array}{r}\text { Asset } \\
\text { volatility }\end{array}$ & $\begin{array}{r}\text { Market } \\
\text { value of } \\
\text { purchased } \\
\text { bond } \\
\end{array}$ & $\begin{array}{r}\text { Default } \\
\text { option value } \\
\text { of } \\
\text { purchased } \\
\text { bond } \\
\end{array}$ & $\begin{array}{r}\text { Market valuc } \\
\text { discount for } \\
\text { credit risk as } \\
\text { a percentage } \\
\text { of the risk } \\
\text { free value of } \\
\text { par }\end{array}$ & $\begin{array}{r}\text { Par value } \\
\text { of funding } \\
\text { subdebt }\end{array}$ & $\begin{array}{l}\text { Market } \\
\text { value of } \\
\text { funding } \\
\text { subdebt }\end{array}$ & $\begin{array}{r}\text { Par value } \\
\text { of insured } \\
\text { deposits }\end{array}$ & $\begin{array}{r}\text { Risk free } \\
\text { market } \\
\text { value of } \\
\text { insured } \\
\text { deposits }\end{array}$ & $\begin{array}{r}\text { Regulatory } \\
\text { equity capital } \\
\text { requirement }\end{array}$ & $\begin{array}{r}\text { Regulatory } \\
\text { equity capital } \\
\text { requirement as } \\
\text { percentage of } \\
\text { market value } \\
\text { of the assel }\end{array}$ & $\begin{array}{r}\text { Market } \\
\text { value of } \\
\text { insurcd } \\
\text { deposits } \\
\text { without } \\
\text { guarantee } \\
\end{array}$ & $\begin{array}{r}\text { Market } \\
\text { value of } \\
\text { safety net } \\
\text { guarantee }\end{array}$ & $\begin{array}{r}\text { Market } \\
\text { value of } \\
\text { safety net } \\
\text { guarantec in } \\
\text { basis points } \\
\text { of asset } \\
\text { market } \\
\text { value }\end{array}$ \\
\hline 0.05 & 99.06 & 3.68 & 3.58 & 2.09 & 1.98 & 89.07 & 84.72 & 12.35 & 12,47 & 84.72 & 0.00053 & 0.05 \\
\hline 0.10 & 97.18 & 5.55 & 5.41 & 2.05 & 1.94 & 73.04 & 73.04 & 22.19 & 22.84 & 73.04 & 0.00199 & 0.20 \\
\hline 0.15 & 95.21 & 7.52 & 7.32 & 2.01 & 1.90 & 62.79 & 62.79 & 30.52 & 32.05 & 62.79 & 0.00318 & 0.33 \\
\hline 0.20 & 93.22 & 9.51 & 9.26 & 1.96 & 1.86 & 53.81 & 53.81 & 37.55 & 40,28 & 53.80 & 0.00392 & 0.42 \\
\hline 0.25 & 91.22 & 11.51 & 11.20 & 1.92 & 1.82 & 45.97 & 45.97 & 43.43 & $47.6 \mathrm{i}$ & 45.96 & 0.00431 & 0.47 \\
\hline 0.30 & 89.23 & 13.50 & 13.14 & 1.88 & 41.14 & 39.14 & 39.14 & 48.31 & 54.14 & 39.13 & 0.00454 & 0.51 \\
\hline
\end{tabular}

Source: Regulatory capital requirements for credit risk under a 2 percent market value (minimum), 20 basis point default rate (one-year maximum) mandatory subordinatcd debt issuance requirement.

The assumptions underlying the calculations are: the initial value of the underlying assets $=100$, the part value of the purchased bond $=108$, bond maturity $=$ one-year, the risk free rate $=5$ percent, and

the market price of risk $=5$ percent.

Table 2. Regulatory Capital Requirements When Asset Maturity Exceeds Funding Debt

\begin{tabular}{|c|c|c|c|c|c|c|c|c|c|c|c|c|}
\hline $\begin{array}{r}\text { Asset } \\
\text { volatility }\end{array}$ & $\begin{array}{r}\text { Market } \\
\text { value of } \\
\text { purchased } \\
\text { bond }\end{array}$ & $\begin{array}{r}\text { Default } \\
\text { option value } \\
\text { of } \\
\text { purchased } \\
\text { bond }\end{array}$ & $\begin{array}{r}\text { Market value } \\
\text { discount for } \\
\text { credit risk as } \\
\text { a percentage } \\
\text { of the risk } \\
\text { free value of } \\
\text { par }\end{array}$ & $\begin{array}{r}\text { Par value } \\
\text { of funding } \\
\text { subdebt }\end{array}$ & $\begin{array}{c}\text { Market } \\
\text { value of } \\
\text { funding } \\
\text { subdebt }\end{array}$ & $\begin{array}{r}\text { Par value } \\
\text { of insured } \\
\text { deposits }\end{array}$ & $\begin{array}{r}\text { Risk free } \\
\text { market } \\
\text { value of } \\
\text { insured } \\
\text { deposits }\end{array}$ & $\begin{array}{r}\text { Regulatory } \\
\text { equity capital } \\
\text { requirement }\end{array}$ & $\begin{array}{r}\text { Regulatory } \\
\text { equity capital } \\
\text { requirement as } \\
\text { percentage of } \\
\text { market value } \\
\text { of the asset }\end{array}$ & $\begin{array}{r}\text { Market } \\
\text { value of } \\
\text { insured } \\
\text { deposits } \\
\text { without } \\
\text { guarantee }\end{array}$ & $\begin{array}{r}\text { Market } \\
\text { value of } \\
\text { safety net } \\
\text { guarantee }\end{array}$ & $\begin{array}{r}\text { Market } \\
\text { value of } \\
\text { safcty nct } \\
\text { guarantee in } \\
\text { basis points } \\
\text { of asset } \\
\text { market } \\
\text { value }\end{array}$ \\
\hline 0.05 & 92.03 & 0.93 & 1.00 & 1.94 & 1.84 & 89.21 & 84.86 & 5.33 & 5.79 & 84.86 & 0.00078 & 0.08 \\
\hline 0.1 & 89.24 & 3.72 & 4.00 & 1.88 & 1.78 & 76.96 & 73.20 & 14.25 & 15.97 & 73.20 & 0.00226 & 0.25 \\
\hline 0.15 & 86.12 & 6.84 & 7.36 & 1.81 & 1.72 & 66.20 & 62.97 & 21.42 & 24.88 & 62.97 & 0.00356 & 0.41 \\
\hline 0.2 & 82.92 & 10.04 & 10.80 & 1.75 & 1.66 & 56.78 & 54.01 & 27.25 & 32.86 & 54.01 & 0.00436 & 0.53 \\
\hline 0.25 & 79.71 & 13.25 & 14.25 & 1.68 & 1.68 & 48.56 & 46.20 & 31.92 & 40.05 & 46.19 & 0.00490 & 0.61 \\
\hline 0.3 & 76.51 & 16.45 & 17.69 & 1.61 & 1.61 & 41.41 & 39.39 & 35.59 & 46.52 & 39.39 & 0.00509 & 0.66 \\
\hline 0.5 & 64.05 & 28.91 & 31.10 & 1.35 & 1.35 & 21.21 & 20.17 & 42.60 & 66.50 & 20.17 & 0.00415 & 0.65 \\
\hline
\end{tabular}

Source: Regulatory capital requirements for credit risk under a 2 percent market value (minimum), 20 basis point default rate (one-ycar maximum) mandatory subordinated debt issuance requircment. The assumptions underlying the calculations are: the initial value of the underlying assets $=100$, the par valuc of the purchased bond $=108$, the bond maturity $=$ three years, the risk-frec ratc $=5$ percent, and the market price of risk $=5$ percent. 


\section{REFERENCES}

Avery, R., T. Belton, and M. Goldberg, (1988), "Market Discipline in Regulating Bank Risk: New Evidence from Capital Markets," Journal of Money, Credit and Banking, Vol. 20, (November), pp. 597-610.

Basel Committee on Banking Supervision, 1988, "International Convergence of Capital Measurement and Capital Standards, " (Basel, Switzerland: Bank for International Settlements).

___ 1995, "An Internal Model-Based Approach to Market Risk Capital Requirements," (Basel, Switzerland: Bank for International Settlements).

__ 1999, "Credit Risk Modeling: Current Practices and Applications," (Basel Switzerland: Bank for International Settlements).

-... 2001, "The New Basel Accord," (Basel, Switzerland: Bank for International Settlements).

Bankers Roundtable, 1998, "Market-Based Incentive Regulation and Supervision: A Paradigm for the Future," Washington.

Beder, T., 1995, "VAR: Seductive but Dangerous," Financial Analysts Journal, (September/October) pp. 12-24.

Benston, G., R. Eisenbeis, P. Horvitz, E. Kane, and G. Kaufman, 1986, "Perspectives on Safe and Sound Banking, " (Cambridge, Massachusetts: MIT Press).

Berger, A., and S. Davies, 1998, "The Information Content of Bank Examinations," Journal of Financial Services Research, Vol. 14, (October), pp. 117-44.

Black, F., and M. Scholes, 1973, "The Pricing of Options and Corporate Liabilities," Journal of Political Economy, Vol. 81 (May-June), pp. 637-54.

Calomiris, C., 1997, "The Postmodern Bank Safety Net: Lessons from Developed and Developing Countries," (Washington: American Enterprise Institute). -, 1999, "Building an Incentive-Compatible Safety Net," Journal of Banking and Finance Vol. 23, No. 10, (October), pp. 1499-519.

Chan, Y., S. Greenbaum, and A. Thakor, 1992, "Is Fairly Priced Deposit Insurance Possible?" Journal of Finance, Vol. 47, No. 1, (March), pp. 227-45.

Christoffersen, P., 1998, "Evaluating Interval Forecasts," International Economic Review, Vol. 39, No. 4, (November), pp. 841-62.

Cooper, K., and D. Fraser, 1988, "The Rising Cost of Bank Failures: a Proposed Solution," Journal of Retail Banking, Vol. 10, pp. 5-12. 
Craine, R., (1995), "Fairly Priced Deposit Insurance and Bank Charter Policy," Journal of Finance, Vol. 50, No. 5, (December), pp. 1735-46.

CreditMetrics Technical Document, 1997, (New York: J.P. Morgan \& Company).

DeYoung, R., M. Flannery and S. Sorescu, 2001, "The Information Content of Bank Exam Ratings and Subordinated Debt Prices," Journal of Money, Credit and Banking, (November), pp. 900-25.

Duffie, D., and J. Pan, 1997, "An Overview of Value at Risk," Journal of Derivatives, Vol. 4, No. 3 (Spring), pp. 7-49.

Esty, B., 1998, "The Impact of Contingent Liability on Commercial Bank Risk Taking," Journal of Financial Economics, Vol. 47, No.2, (February), pp. 189-212.

Evanoff, D., 1993, "Preferred Sources of Market Discipline," Yale Journal of Regulation, Vol. 10, No. 3, pp 347-67. , and L. Wall, 2000, "Subordinated Debt as Bank Capital: A Proposal for Regulatory Reform," Federal Reserve Bank of Chicago Economic Perspectives, Vol. 24, No. 2, pp. $40-53$.

Federal Deposit Insurance Corporation, 1983, "Deposit Insurance in a Changing Environment: A Study of the Current System of Deposit Insurance Pursuant to Section 712 of the Garn-St. Germain Depository Institutions Act of 1982," A Report to Congress on Deposit Insurance. Washington, D.C.: Government Printing Office, (June).

Federal Reserve Board, 1999, "Using Subordinated Debt as an Instrument of Market Discipline, "Staff Study 172, Board of Governors of the Federal Reserve System, (December).

Financial Services Roundtable, 2001, "Re: The New Basel Accord: January 2001 Consultative Papers," accessible on the Bank for International Settlements website, www.bis.org.

Flannery, M., 1989, "Capital Regulation and Insured Bank's Choice of Individual Loan Default Risks," Journal of Monetary Economics, Vol. 24, No. 2, (September), pp. 235-58.

__ _- and S. Sorescu, 1996, "Evidence of Bank Market Discipline in Subordinated Debt Yields: 1983-1991," Journal of Financial Services Research, Vol. 20, No. 2-3, (October-December), pp. 107-99.

Genotte, G., and D. Pyle, 1991, "Capital Controls and Bank Risks," Journal of Banking and Finance, Vol. 15, No. 4/5, (September) pp. 804-24.

Geske, R., 1977, "The Valuation of Corporate Liabilities as Compound Options," Journal of Financial and Quantitalive Analysis, Vol. 12, (November), pp. 541-52. 1979, "The Valuation of Compound Options," Journal of Financial Economics, Vol. 7, No. 1, (March), pp. 63-81. 
Gorton, G., and A. Santomero, 1990, "Market Discipline and Bank Subordinated Debt," Journal of Money, Credit and Banking, Vol. 22, No. 1, (February), pp. 119-28.

Hancock, D., and M. Kwast, 2001, "Using Bond and Stock Markets to Monitor Bank Holding Companies: Is It Feasible?" Journal of Financial Services Research, Vol. 20, No. 2-3, (October-December), pp. 147-87.

Hassan, M., G. Karels, and M. Peterson, 1994, "Deposit Insurance, Market Discipline and OffBalance Sheet Banking Risk of Large U.S. Commercial Banks," Journal of Banking and Finance, Vol. 18, No. 3, (May), pp. 575-93.

Horvitz, P., 1983, "Market Discipline is Best Provided by Subordinated Creditors," American Banker, (July).

— 1986, "Subordinated Debt is Key to New Bank Capital Requirement," American Banker, (December).

Hull, J., and A. White, 1998, "Value at Risk When Daily Changes in Market Variables Are Not Normally Distributed," Journal of Derivatives, Vol. 5, No. 3, (Spring) , pp. 9-19.

Institute of International Finance, 2001, "Report of the Working Group on Capital Adequacy," Washington, D.C., accessible on the Bank for International Settlements website, www.bis.org.

ISDA, 2001, "ISDA's Response to the Basel Committee on Bank Supervision's Consultation on The New Capital Accord," accessible on the Bank for International Settlements website, www.bis.org.

Jorion, P., 1995, "Measuring the Risk in Value at Risk," Financial Analysts Journal", (November/December), pp. 47-56.

— 1997, Value at Risk, (New York: McGraw Hill).

Kaufmann, G., R. Litan, R. Aspinwall, G. Benston, C. Calomiris, F. Edwards, S. Harrington, R. Herring, P. Horritz, R. Romano, H. Scott, K. Scott, and P. Wallison, 2000, "Reforming Bank Capital Regulation," Washington D.C., The AEI Press, (March).

KPMG, 2001, "The New Basel Accord: Response to Consultative Documents dated January 2001," accessible on the Bank for International Settlements website, www.bis.org.

Kupiec, P., 1995, "Techniques for Verifying the Accuracy of Risk Measurement Models," Journal of Derivatives, Vol. 3, (Winter), pp. 73-84.

—, 1999, "Risk Capital and VaR," The Journal of Derivatives, Vol. 7, No. 2, (Winter), pp. 41-52.

_ 2001a, "Estimating Credit Risk Capital: What's the Use?" The Journal of Risk Finance, Vol. 2, No. 3 (Spring), pp. 17-34. 
,2001b, "Is the New Basel Accord Incentive Compatible?" draft December 2001, available at www.bis.org.

— 2002a, "What Exactly Does Credit VaR Measure?" The Journal of Derivatives, Vol. 9, No. 3 (Spring), pp. 46-59.

__ 2002b, "Calibrating Your Intuition: Capital Allocation for Market and Credit Risk," IMF Working Paper WP/02/99, (June).

___ 2002c, "Internal Models Capital Regulation and Bank Risk-Taking Incentives," IMF Working Paper WP/02/125, (July).

- _- and J. O'Brien, 1998, "Deposit Insurance, Bank Incentives, and the Design of Regulatory Policy," Finance and Economic Discussion Series No. 1998-10, Board of Governors of the Federal Reserve System, http:/www.federalreserve.gov/pubs/feds/1998/index.html.

Litan, R., and J. Rauch, 1997, "Finance for the $21^{\text {st }}$ Century," U.S. Treasury, Government Printing Office, (November).

Marshall, C., and M. Siegel, 1997, "Value-at-Risk: Implementing a Risk Measurement Standard," Journal of Derivatives, Vol. 4, No. 3 (Spring), pp. 16-24.

Matten, C., 1997, "Managing Bank Capital: Capital Allocation and Performance Measurement." (Chichester, England: John Wiley \& Sons).

Merton, R., 1974, "On the Pricing of Corporate Debt: The Risk Structure of Interest Rates," Journal of Finance, Vol. 29 (May), pp. 449-70.

__ 1977, "An Analytic Derivation of the Cost of Deposit Insurance and Loan Guarantees: An Application of Modern Option Pricing," Journal of Banking and Finance, Vol. 1, (June), pp. 3-11.

O'Hara, M., and W. Shaw, 1990, "Deposit Insurance and Wealth Effects: The Value of Being "Too Big to Fail," Journal of Finance, Vol. 45, No. 5, (December), pp. 1587-1600.

Osterberg, S., and W. Thomson, 1991, "The Effect of Subordinated Debt and Surety Bonds on the Cost of Capital for Banks and the Value of Federal Deposit Insurance," Journal of Banking and Finance, Vol. 15, No. 4-5 (September), pp. 939-53.

Rochet, J., 1992, "Capital requirements and the behavior of commercial banks," European Economic Review, Vol. 36, No. 5, (June), pp. 1137-78.

Sironi, A., 2001 "An Analysis of European Banks' SND Issues and Its Implications," Journal of Financial Services Research, Vol. 20, (October-December), pp. 233-66.

Wall, L., 1989, "A Plan for Reducing Future Deposit Insurance Losses: Putable Subordinated Debt," Economic Review, Federal Reserve Bank of Atlanta, (July/August), pp. 2-17. 